\title{
ACUTE KIDNEY DAMAGE IN PREGNANCY: ETIOPATHOGENESIS, DIAGNOSTICS AND BASIC PRINCIPLES OF TREATMENT
}

Branislava Draskovic, Tomislav Nikolic ${ }^{1,3}$, Sasa Jacovic ${ }^{2}$ and Dejan Petrovic ${ }^{1,3}$

${ }^{1}$ Clinic of Urology, Nephrology and Dialysis, Clinical center Kragujevac, Kragujevac, Serbia

${ }^{2}$ Medicines and Medical Devices Agency of Serbia, Belgrade, Serbia

${ }^{3}$ University of Kragujevac, Faculty of Medical Sciences, Kragujevac, Serbia

\section{AKUTNO OŠTEĆENJE BUBREGA U TRUDNOĆI: ETIOPATOGENEZA, DIJAGNOSTIKA I OSNOVNI PRINCIPI LEČENJA}

\author{
Branislava Drašković, Tomislav Nikolić ${ }^{1,3}$, Saša Jaćović ${ }^{2}$ Dejan Petrovićc ${ }^{1,3}$ \\ ${ }^{1}$ Klinika za urologiju, nefrologiju i dijalizu, Klinički centar Kragujevac, Kragujevac, Srbija \\ ${ }^{2}$ Agencija za lekove i medicinska sredstva Srbije, Beograd, Srbija \\ ${ }^{3}$ Univerzitet u Kragujevcu, Fakultet medicinskih nauka, Kragujevac, Srbija
}

\begin{abstract}
Acute kidney damage associated with pregnancy occurs in 1/20.000 pregnancies. In developing countries, the main cause of the development of acute kidney damage is septic abortion, and preeclampsia in the developed countries of the world. Preeclampsia is defined as newly developed hypertension, proteinuria and swelling in pregnant women after the 20th week of gestation. It occurs due to disorders in the development of placenta and systemic disorders of the function of the endothelium of the mother. It is treated with methyldopa, magnesium sulfate and timely delivery. Urgent delivery is indicated if the age of gestation is $\geq 34$ weeks. HELLP syndrome is a difficult form of preeclampsia. Its main characteristics are decreased platelet count, microangiopathic hemolysis anemia, increased concentration of aminotransferase in the serum and acute kidney damage. Severe HELLP syndrome is treated with emergency delivery, antihypertensives, magnesium sulfate, and in some cases plasmapheresis and hemodialysis. Acute fatty liver in pregnancy occurs because of decreased activity of the LCHAD enzyme of the fetus. Due to the reduced beta oxidation of fatty acids in the hepatocytes of the fetus, long chain fatty acids that cause damage to the mother's hepatocytes are released. Swansea criteria are used for diagnosis, and the difficult form of the disease is treated with plasmapheresis and extracorporeal liver support. Atypical HUS is due to a reduced protein activity that regulates the activity of the alternative pathway of the complement system. Its main features are thrombocytopenia, microangiopathic hemolytic anemia and acute kidney damage. It is treated with plasmapheresis, and in case of resistance with eculizumab. Thrombotic thrombocytopenic purpura is due to decreased activity of the ADAMTS13 enzyme. It is characterized by thrombocytopenia, microangiopathic hemolytic anemia, high temperature, nervous system disorders and acute kidney damage. It is treated with plasmapheresis, and severe form of disease with corticosteroids and azathioprine. Early detection and timely treatment of acute kidney damage provides a good outcome for the mother and fetus.
\end{abstract}

Keywords: acute kidneydamage, pregnancy, preeclampsia, eclampsia, HELLP syndrome, thrombotic microangiopathies

\section{SAŽETAK}

Akutno oštećenje bubrega povezano sa trudnoćom javlja se kod 1/20.000 trudnoća. U zemljama u razvoju, glavni uzrok razvoja akutnog oštećenja bubrega je septički abortus, a u razvijenim zemljama sveta preeklampsija. Preeklampsija se definiše kao novonastala hipertenzija, proteinurija i otoci kod trudnica posle 20. nedelje gestacije. Nastaje zbog poremećaja u razvoju placente $i$ sistemskog poremećaja funkcije endotela majke. Leči se metildopom, magnezijum sulfatom i pravovremenim porođajem. Hitan porođaj je indikovan ukoliko je starost gestacije $\geq 34$ nedelje. HELLP sindrom je težak oblik preeklampsije. Njegove glavne karakteristike su smanjen broj trombocita, mikroangiopatska hemolizna anemija, povećana koncentracija aminotransfeaza u serumu i akutno oštećenje bubrega.Težak HELLP sindrom leči se hitnim porođajem, antihipertenzivima, magnezijum sulfatom, a u pojedinim slučajevima plazmaferezom i hemodijalizom. Akutna masna jetra u trudnoći nastaje zbog smanjene aktivnosti enzima LCHAD ploda. Zbog smanjene beta oksidacije masnih kiselina u hepatocitima ploda, oslobađaju se masne kiseline dugih lanaca koje izazivaju oštećenje hepatocita majke. Za dijagnostikovanje se koriste Swansea kriterijumi, a težak oblik bolesti leči se plazmaferezom i vantelesnom jetrinom potporom. Atipični HUS nastaje zbog smanjene aktivnosti proteina koji regulišu aktivnost alternativnog puta sistema komplementa. Njegove glavne karakteristike su trombocitopenija, mikroangiopatska hemolizna anemija i akutno oštećenje bubrega. Leči se plazmaferezom, a u slučaju rezistencije ekulizumabom.Trombotična trombocitopenijska purpura nastaje zbog smanjene aktivnosti enzima ADAMTS13. Karakteriše se trombocitopenijom, mikroangiopatskom hemoliznom anemijom, visokom temperaturom, poremećajima nervnog sistema i akutnim oštećenjem bubrega. Leči se plazmaferezom, a teže bolesti kortikosteroidima i azatioprinom. Rano otkrivanje i pravovremeno lečenje akutnog oštećenja bubrega obezbeđujedobar ishod i majke i ploda.

Ključne reči: akutno oštećenje bubrega, trudnoća, preeklampsija, eklapmsija, HELLP sindrom, trombotične mikroangiopatije

\section{sciendo}

UDK: 616.61-055.26

Ser J Exp Clin Res 2020; 21 (2): 113-119

DOI: $10.1515 /$ sjecr-2017-0058
Corresponding author: Branislava Draskovic Clinic of Urology, Nephrology and Dialysis, Clinical center Kragujevac Zmaj Jovina street 30, 34000 Kragujevac, Republic of Serbia Tel.: 034-370-302, Fax: 034-370-302
E-mail: brankicaaa-kg@hotmail.com 


\section{INTRODUCTION}

Acute kidney related damage associated with pregnancy - PR-AKI is a significant cause of morbidity and mortality of mother and fetus $(1,2)$. In the last decade, the incidence of acute kidney damage associated with pregnancy is reduced and currently stands at $1 / 20.000$ pregnancies. This reduction, especially in developing countries, is due to the legalization and reduction of the incidence of septic abortion, better equipment of obstetric units and better monitoring of pregnant women and fetuses $(1,2)$. In developing countries, the major cause of the development of acute kidney damage associated with pregnancy is sepsis, and preeclampsia in the developed countries of the world $(1,2)$.

\section{Definition of acute kidney damage associated with pregnancy}

The definition and classification of acute kidney damage in pregnancy is not entirely clear, due to open questions, such as: the optimal method for measuring the strength of glomerular filtration and adaptive changes in the kidney during pregnancy. The strength of glomerular filtration in pregnancy is significantly increased (approximately 50\%), resulting in a low basal concentration of creatinin in serum, compared to healthy non-pregnant women $(1,2)$. New classifications for acute kidney damage, such as RIFLE (Risk, Injury, Failure, Loss, and End-stage kidney disease criteria - RIFLE), AKIN (Acute Kidney Injury Network - AKIN) and KDIGO (Kidney Disease Improving Global Outcomes) have not been validated in the pregnant population $(1,2)$. Acute kidney damage associated with pregnancy is defined as a serum creatinine concentration greater than $71 \mu \mathrm{mol} / \mathrm{l}$ (normal serum creatinine concentration in the third trimester of pregnancy is 62$71 \mu \mathrm{mol} / \mathrm{l})$ in pregnant women in the absence of clinical data for chronic kidney disease, $(1,2)$. Any increase in the serum creatinine concentration of $8.8 \mu \mathrm{mol} / \mathrm{l}(0.1 \mathrm{mg} / \mathrm{dl})$ in pregnant women can indicate the development of acute kidney damage $(1,2)$.

\section{Etiopathogenesis of acute kidney damage associated with pregnancy}

Depending on the etiology, we can distinguish three types of acute kidney damage associated with pregnancy: prerenal, renal, and postrenal type $(1,2)$. Pregnant type of acute kidney damage occurs most often in the first trimester of pregnancy and is caused by kidney hypoperfusion of the kidney: excessive vomiting (hyperemesis gravidarum), severe bleeding (separation of placenta, abortion) and septic shock (abortion complicated by sepsis) $(1,2)$. Renal type of acute kidney damage most commonly occurs in the third trimester of pregnancy as a result of preeclampsia, HELLP syndrome (Hemolysis, Elevated Liver enzymes and Low Platelet count HELLP), Acute Fatty Liver in Pregnancy - AFLP and thrombotic microangiopathy - aHUS/TTP (Atypical HemolyticUremic Syndrome aHUS/Thrombotic Thrombocytopenic Purpura - TTP) (1, 2). Postrenal type of acute kidney damage occurs due to obstruction of the urinary tract: hydronephrosis due to pressure of the enlarged uterus and damage to the ureter or bladder during the caesarean section $(1,2)$.

\section{Preeclampsia and eclampsia}

Preeclampsia is defined as newly emerging hypertension, proteinuria and swelling in pregnant women after the 20th week of gestation (3-7). Hypertension was defined as arterial blood pressure $\geq 140 / 90 \mathrm{mmHg}$ (systolic arterial blood pressure $\geq 140 \mathrm{mmHg}$ or diastolic blood pressure $\geq 90 \mathrm{mmHg}$ ), in at least two measurements with the interval of at least 4$6 \mathrm{~h}$, after 20th week of gestation in women who previously had normal arterial blood pressure (3-7). Proteinuria is defined as secretion of proteins through urine in an amount of $\geq 300 \mathrm{mg} / 24 \mathrm{~h}$ (3-7). Severe pre-eclampsia is defined as one or more ancillary criteria: systolic blood pressure $\geq 160$ $\mathrm{mmHg}$ or diastolic blood pressure $\geq 110 \mathrm{mmHg}$ in two measurements with a gap of maximum 6 hours, proteinuria $\geq 5.0$ $\mathrm{g} / 24 \mathrm{~h}$, oliguria (urine output $<500 \mathrm{ml} / 24 \mathrm{~h}$ ), severe headache, altered state of consciousness, pulmonary edema, liver damage, thrombocytopenia $(<100 \times 109 / 1)$, HELLP syndrome, delay in fetal growth (3-7). It occurs in 3-8\% of pregnancies in the developed countries of the world, and the main risk factors for its occurrence are: first pregnancy, pregnancy with multiple fetuses, anamnestic data of pre-eclampsia during previous pregnancy, kidney disease, chronic hypertension, obesity, diabetes mellitus, systemic erythema lupus, antiphospholipid syndrome, thrombophilia, mother's age ( $>35$ 40 years) (3-7). Basically it is a disorder of the development of the placenta (placental ischemia), disorder of balance between factors that promote vascular development(Vascular Endothelial Growth Factor - VEGF and Placental Growth Factor - PIGF) and factors that block formation of new blood vessels (soluble Fms-like tyrosine kinase 1 - sFlt-1 and soluble Endoglin - sEng) and systemic endothelial dysfunction of the mother, Scheme 1 (3-7). In preeclampsia there is a disorder in the transformation of cytotrophoblasts into endothelial cells and the disorder of their inclusion in the endothelial spiral arteries of the mother's womb. Blood vessels remain small, provide great resistance to blood flow, causing decreased perfusion of placenta and its ischemia (3-7). In conditions of ischemia, the placenta increases the releasing factors which block the formation of new blood vessels (sFlt$1 /$ sEng), causing the systemic endothelial dysfunction of the mother (decreased production of nitric oxide and prostacyclin, the release of procoagulant proteins) and insufficiency of multipleorgan systems (kidney, heart, brain, liver) (3-7). The relationship of sFlt-1/PIGF $\geq 85$ indicates preeclampsia and allows the isolation of pregnant women who have an increased risk of serious complications associated with pre-eclampsia (3-7).Treatment consists in prevention of preeclampsia and timely delivery (age of gestation, maternal condition, condition of the fetus). To prevent development of preeclampsia, low molecular weight heparin, calcium preparations (1.5 g/day) and L-arginine can be used. For the treatment of hypertension, first line medicines are methyldopa, labetalol and hydralazine (3-7). Metildopa is administered per os in a dose of 0.5-3.0 g/24h, in 2-4 divided doses. Magnesium sulfate is used to prevent eclampsia (newly tone- 
clonal cramps). The magnesium sulfate impact dose is 4-6 g i.v. for 15 minutes, then, it should be continued with a maintenance dose of $1.0 \mathrm{~g} / \mathrm{h}$ in the form of continuous i.v. infusion (concentration of magnesium in the serum should be 480-840 mg/l) (3-7). In pregnant women with mild preeclampsia, and the period of gestation $\geq 37$ weeks a delivery is indicated (delivery is effective for optimal disease control and favorable outcome of mother and fetus). If the period of gestation is less than 37 weeks, it is necessary to monitor the pregnant woman and the fetus. Monitoring of pregnant women with mild preeclampsia includes daily monitoring of vital functions, assessment of hemodynamic status, laboratory analysis once a week: blood count, platelet count, serum creatinine concentration, serum transaminases. Fetal monitoring includes a mobility test, a biophysical profile, and a serial measurement of fetal growth every three weeks $(6,7)$. Among the indications for delivery of pregnant women with mild preeclampsia with less than 37 weeks of gestation and in which adequate pregnancy and fetus monitoring is applied, there are: worsening of the condition of the mother, deterioration of the fetal condition, birth pain or rupture of the placenta before birth pains and achieved gestation age $(\geq 37$ weeks) $(6,7)$. In pregnant women with severe preeclampsia, whose gestation age is less than 28 weeks, a termination of pregnancy is indicated. If the age of gestation is $\geq 34$ weeks, emergency delivery is indicated. If delivery is not directly indicated (age of gestation from 28-34 weeks), there is application of magnesium sulfate (prevention of eclampsia development), corticosteroids for stimulation of lung maturation for 24-48 hours (dexamethasone $6 \mathrm{mg} / 12 \mathrm{~h}$ i.m. (four doses of the drug) and enhanced monitoring of mother and fetus. Emergency delivery is indicated in the following cases: uncontrolled severe hypertension, development of eclampsia, development of HELLP syndrome, edema of the lungs, acute kidney damage, placental depletion, slow growth of fetus, biophysical profile $\leq 4 / 10$ in more than two consecutive sixhour periods, reversible diastolic flow through the umbilical artery $(6,7)$.

\section{HELLP syndrome}

HELLP syndrome is a difficult form of preeclampsia characterized by a reduced number of platelets, microangiopathichemolytic anemia, increased serum aminotransferase concentrations, and acute kidney damage (8). This syndrome occurs in $0.5-0.9 \%$ of pregnancies, and in $10-20 \%$ of pregnant women with severe pre-eclampsia (in $70 \%$ of pregnant women it occurs between 27-37 weeks of gestation, it can occur within 48 hours after delivery) (8). It is clinically manifested by headache, pain, disgust, vomiting, and pain in the upper right quadrant of the abdomen. The most important complications of the HELLP syndrome are: disseminated intravascular coagulopathy, placental abruption, acute renal failure, pulmonary edema, hepatic subcapsular hematoma and retinal detachment (8-10). Microangiopathichemolytic anemia is importantfor diagnosis of HELLP syndrome (increased number of reticulocytes and schizocytes, decreased concentration of haptoglobin in the serum, increased concentration of lactate dehydrogenase, bilirubin and aminotrans- ferases in the serum, and reduced platelet count). It occurs due to the passage of erythrocytes through the narrowing's, which are caused by damage to the endothelium and the deposition of fibrin on its surface in small blood vessels of various organs, including the kidney (glomerular endotheliosis) (8-10). Severe HELLP syndrome is defined as a platelet count less than $50^{\times} 10^{9} / 1$, the concentration of aspartate aminotransferase - AST $\geq 70$ IU/1 and lactate dehydrogenase LDH $\geq 600 \mathrm{IU} / 1$ (HELLP class I) (8-10). Treatment of HELLP syndrome includes application of magnesium sulfate ( $4.0 \mathrm{~g}$ i.v. bolus, and then continue to $1.0 \mathrm{~g} / \mathrm{h}$ during 24 hours after birth), corticosteroids (protocol for fetal lung maturation) and urgent delivery (8-10). When HELLP syndrome is diagnosed early and promptly and vigorously treated, the majority of pregnant women improve the condition within 2448 hours after birth: there is increasing of the number of platelets and significant decrease in concentration of liver enzymes in serum (8-10). Extremely rarely, after delivery, the condition of the pregnant woman may be exacerbated by the development of multiple organ system insufficiencies. In these pregnant women, the clinical condition is corrected by the use of plasmapheresis [category III (postpartum): individual benefit/risk assessment, gradus 2C: poor recommendations] (9-12). Plasmapheresis should be administered 24-72 hours after birth, when there was no increase in platelet count $\left(\geq 100^{\times} 10^{9} / \mathrm{l}\right.$ ) and no reduction of the concentration of liver enzymes (ALT), and when acute renal failure, respiratory distress syndrome or neurological disordersare developed (9-12). Plasmapheresis is applied every 24-48h, 3000-4000 $\mathrm{ml}$ of plasma is changed, and fresh frozen plasma is used for substitution (9-12). Through plasmapheresis, procoagulant factors that are released from the platelets and endothelial cells are removed. The criteria for termination of plasmapheresis include: platelet counts greater than $100 \times 10^{9} / 1$ and stable condition of pregnant women (9-12).

\section{Acute fatty liver}

Acute Fatty Liver in Pregnancy - AFLP is an emergency situation in obstetrics, which may cause the progressive and fulminant hepatic failure (13-15). The incidence of acute fatty liver in pregnancy is $1 / 10,000$ to 20,000 pregnancies, and the onset of the disease is generally between 30 and 38 weeks of gestation (13-15). The disease occurs as a result of decreased activity of LCHAD (Long-Chain 3-Hydroxyl Coenzyme A Dehydrogenase - LCHAD) of the fetus (genetic error). This enzyme is significant for the beta oxidation of fatty acids in the fetus hepatocyte mitochondria. Due to deficiencies and reduced function of this enzyme, fatty acids with long-chain are released from hepatocytes, which by means of the circulation arrive to the liver of the pregnant women and induce damage to the hepatocytes (13-15). The disease is manifested through nausea, disgust, vomiting, pain in the upper right quadrant of the abdomen, hypoglycemia, lactic acidosis, and with progression of damage acute liver failure and hepatic encephalopathy can be developed (13-15). The diagnosis is made on the basis of „Swansea” criteria: vomiting, abdominal pain, polydipsia/polyuria, encephalopathy, ascites, or light liver on ultrasound examination, increased 
bilirubin levels in the serum ( $>14 \mu \mathrm{mol} / \mathrm{l})$, increased concentration of uric acid in serum $(>340 \mu \mathrm{mol} / \mathrm{l})$, leukocytosis (>11 $\times 10^{9} /$ ), hypoglycemia (glucose concentration in serum is less than $4.0 \mathrm{mmol} / \mathrm{l}$ ), increased concentrations of transaminases in serum ( $>42 \mathrm{IU} / \mathrm{l})$, increased concentration of ammonia in the serum ( $>47 \mu \mathrm{mol} / \mathrm{l})$, impaired renal function (serum creatinine concentration $>150 \mu \mathrm{mol} / \mathrm{l}$ ), coagulopathia $(\mathrm{PT}>14 \mathrm{~s}$, aPTT $>34 \mathrm{~s})$, microvesicular steatosis demonstrated by liver biopsy. Acute fatty liver in pregnancy is diagnosed if $\geq 6$ criteria are present, and in the absence of another cause of liver damage (13-15). After delivery, a gene mutation screening is advised (the gene responsible for the synthesis of LCHAD) in neonates and pregnant women with AFLP and HELLP syndrome (13-15). Treatment consists of the optimal control of glycemia and coagulopathy (fresh frozen plasma, cryoprecipitate). Hepatic encephalopathy is treated with a hypoprotein diet and lactulose (per os). The last clinical experience indicates the benefit of plasmapheresis and MARS (Molecular Adsorbent Recirculating Systems $M A R S$ ) modality of extracorporeal support of liver (13-15).

\section{Atypical haemolytic-uremic syndrome - aHUS}

Pregnancy-Related atypical Hemolytic-Uremic Syndrome- P-aHUS is an emergency situation in obstetrics, which may cause progressive acute renal failure (16-19). The incidence of apregnancy-related atypical hemolytic-uremic syndrome is $1 / 25,000$ pregnancies, and basically it is a disorder of regulation of the alternative pathway of the complement system (increased activity results in damage to the endothelial cells and the formation of clots in the small blood vessels of the kidney) (16-19). The increased activity of the alternative pathway of the complement system is caused by mutations in the genes encoding three major proteins (blockers) which regulate the activity of the alternative pathway of the complement system: factor $\mathrm{H}$ - Complement Factor $\mathrm{H}$ CHF, factor I - Complement Factor I - CFI and Membrane cofactor protein - MCP. In addition to mutations of genes, important role in the pathogenesis of aHUS CDs have acquired autoantibodies against factor $\mathrm{H}$ of the complement system (anti-CFH antibodies) (16-19). aHUS associated with pregnancy generally occurs after delivery (postpartum period). Diagnosis of atypical hemolytic uremic syndrome includes: measuring the level of C3 and C4 components of complement in serum, the test for demonstrating C3 nephritic factor - C3NF, measuring the concentration of CFH, CFI, MCP in serum, analysis of gene mutation for CFH, CFI, MCP, and determination of the anti-CFH antibody titre (16-19). For the differential diagnosis of aHUS, a concentration of liver enzymes (HELLP syndrome), ADAMTS13 activity (thrombotic thrombocytopenic purpura - TTP) and tests for the diagnosis of autoimmune diseases (trigger for the development of aHUS) should be made: antinuclear antibodies - ANA and anti-dsDNA antibodies (systemic lupus erythematous), antibodies against antigens in the cytoplasm of neutrophils - ANCA (vasculitis) antiphospholipid antibodies: lupus anticoagulant (LA), and cardiolipin antibodies (aCL), anti- $\beta 2-G P I$ antibodies (antiphospholipid syndrome), antiScl-70 antibodies (Systemic sclerosis) (16-19). In patients with aHUS a first line of treatment is plasmapheresis (16-20). Through plasmapheresis, the non-functional proteins which regulate the activity of the alternative pathway of the complement system (CFH, CFI, CFB, C3) are removed, as well as autoantibodies to the CFH (anti-CFH antibodies) (16-20). Plasmapheresis should be administered within 24 hours of clinical manifestation of aHUS, daily for 3-5 days, changing to $1.0-1.5$ volume of plasma $(60-65 \mathrm{ml} / \mathrm{kg})$ and for substitution is used fresh frozen plasma (16-21). During the treatment with plasmapheresis, daily are determined the number of platelets, the concentration of lactate dehydrogenase and concentration of creatinine in the serum. The aim of the plasmapheresis is to achieve remission of aHUS: normal platelet count ( $\left.\geq 150^{x} 109 / 1\right)$, normal concentration of lactate dehydrogenase in the serum $(<250 \mathrm{IU} / 1)$ and a reduction of creatinine concentration in serum by $>25 \%$ compared to the concentration of creatinine in serum prior to plasmapheresis (1621). In patients with aHUS who are resistant to plasmapheresis (persistent haemolysis, thrombocytopenia, absence of lactate dehydrogenase concentration reduction in serum, absence of creatinineconcentration reductionin serum after five consecutive daily plasmapheresis), a C5 complement component blocker is used (eculizumab: anti-C5 humanized monoclonal antibody) (22-26). Because of the risk of meningococcal infection (Neisseria meningitidis) is necessary to apply meningococcal vaccine at least two weeks prior to the first dose of eculizumab (US Advisory Committee and the Immunization Practices - USACIP) (in pregnant women in postpartum period) or prophylaxis for meningococcal infection (ciprocinal in postpartum period or rifampin in the partal period) in patients that require direct administration of eculizumab (22-27). The treatment consists of two phases: the initial and the maintenance phase. In the initial phase, eculizumab is administered at a dose of $900 \mathrm{mg}$, in the form of i.v. infusion for 25-45 minutes, once a week for four weeks. In the maintenance phase, eculizumab is administered at a dose of $1200 \mathrm{mg}$, in the form of i.v. infusion for 25-45 minutes, on the fifth week, and then every other week until reaching remission (22-26). Evaluation of response to therapy includes monitoring of platelet count, determination of the concentration of creatinine and the lactate dehydrogenase in serum on every two weeks. Remission is defined as the realization of the normal number of platelets, the normal concentration of lactate dehydrogenase and a normal creatinine level in the serum at least in two successive measurements, with a gap of at least four weeks. After administration of eculizumab and achieving complete remission, monitoring is required to detect signs and symptoms of aHUS for a time period of at least 12 weeks (eculizumab provides improved recovery of renal function in relation to plasmapheresis) (22-26).

\section{Thrombotic thrombocytopenic purpura - TTP}

Thrombotic thrombocytopenic purpura (TTP) is a clinical syndrome that is characterized by thrombocytopenia, microangiopathic hemolytic anemia, high body temperature, disorders of the central nervous system and acute renal insuficiency (28-30). It is caused by decreased activity of ADAMTS13 metalloproteinase, an enzyme that ctears apart 
macromolecules ofvon Wilebrand's factor (vWF) secreted by endothelial cells of small blood vessels, and this results in the formation of clots (vWF + platelets), and the narrowing of lumen of the small blood vessels of the brain and kidney (28-30). Depending on the causes leading to reduced ADAMTS13 activity, we distinguish congenital (mutation of gene for ADAMTS13 synthesis) and acquired (antiADAMTS13 IgG antibodies) form of TTP (28-30). In congenital TTP (cTTP), ADAMTS13 activity is $\leq 5 \%$, and for aquired TTP (sTTP) $\leq 10 \%$ (28-30). The incidence of congenital thrombotic thrombocytopenic purpura in pregnancy is $1 / 200,000$ pregnancies. In pregnant women, thrombotic thrombocytopenic purpura is clinically represented by headache, confusion, visual impairment, proteinuria, pre-eclampsia, kidney damage, abdominal pain, embolization of the lungs and acute respiratory distress syndrome (28-30). The congenital form of TTP associated with pregnancy most commonly occurs in the postpartum period (monitoring for cTTP in the postpartum period). Treatment begins with plasmapheresis (plasmapheresis is the first line of therapy) (28-30). It is applied on a daily basis for five days, at least one plasma volume $(2800 \mathrm{ml})$ is changed, and fresh plasma is used to substitute the separated plasma. In patients who are diagnosed with acute acquired form of TTP (anti-ADAMTS13 antibodies) corticosteroids are applied in addition to the plasmapheresis $(1.0 \mathrm{mg} / \mathrm{kg} /$ day per os) and azathioprine (28-30). The aim of the plasmapheresis is to achieve disease remission [number of platelets $>150^{\mathrm{x}}$ $10^{9} / 1$ in the course of two consecutive days, normal or nearly normal concentration oflactate dehydrogenase in the serum $(\mathrm{LDH}<250 \mathrm{IU} / \mathrm{l})$, the stabilization or repair of neurological disorders]. The refractory form of TTP (resistance to plasmapheresis) is defined as the lack of response after five daily sessions of plasmapheresis (the absence of increase in the number of platelets and stabilization of the clinical condition of the patient).With pregnant women with refractory form of TTP, that are clinically unstable and have neurological symptoms, pulse doses of methylprednisolone are applied (Methylprednisolone: $1.0 \mathrm{~g}$ i.v. inf/day during three consecutive days), through plasmapheresis plasma volume of 1.5 is hanged and rituximab is given (i.v. inf.: 375 $\mathrm{mg} / \mathrm{m}^{2} /$ week, for 4 weeks) (life-threatening thrombotic thrombocytopenic purpura) (28-31). In pregnant women who have been previously diagnosed with TTP plasma treatment infusions should be administered between 8-10 weeks of gestation, initially every two weeks, and frequency of infusions of fresh frozen plasma increases every week during the second and early start of the third trimester of pregnancy, or if the platelet count falls below $150^{\times} 10^{9} / \mathrm{l}$ or the concentration of lactate dehydrogenase increases in serum (elective use of fresh frozen plasma), combined with small doses of aspirin (75-100 mg/day) and low molecular weight heparin (28-30). Infusion of fresh frozen plasma is administered every week for six weeks after delivery (postpartum period) (prevention of development of acute episode of cTTP) (28-30). In the acquired form of TTP associated with pregnancy (positive antiADAMTS13 IgG antibodies), prior to conception rituximab should be applied at a dose of $375 \mathrm{mg} / \mathrm{m}^{2} /$ week, in 6 doses [level of anti-ADAMTS13 IgG is reduced below the normal value (normal concentrations of anti-ADAMTS13 is less than $12 \mathrm{IU} / \mathrm{ml}$ ), and the ADAMTS13 activity is increased) (28-30). Twelve months after the administration of rituximab, conception (planned pregnancy) is advised (28-30). For prevention of acute episode of sTPP in pregnancy, infusion of fresh frozen plasma is applied $(10 \mathrm{ml} / \mathrm{kg})$ every other week from 8-10 weeks of gestation until childbirth (when ADAMTS13 activity drops below 10\%, and normal ADAMTS13 activity is 50-100\%), in combination with low doses of aspirin and heparin of low molecular weight [plasmaphresisis used in the acute phase of the disease (acute episodes cTTP/STPP), and for the prophylaxis the infusion of fresh frozen plasma is used] (28-30).

\section{ACUTE DIALYSIS DURING PREGNANCY}

Treatment of acute kidney damage associated with pregnancy consists in the elimination of the cause (volume resuscitation, urgent delivery, timely application of kidney function replacement therapy) (32-34). Acute kidney damage in pregnancy that requires treatment with dialysis occurs in 1.0 at 10.000-15.000 pregnancies. Indications for acute dialysis during pregnancy include: the presence of signs and symptoms of uremia (encephalopathy, pericarditis and neuropathy), volume overload (excess fluid in the body), hyperkalemia and metabolic acidosis that do not respond to the starting/initial therapy (32-34). Daily intermittent hemodialysis is applied (> $20 \mathrm{~h} /$ week), with a slight ultrafiltration (500 ml/dialysis session) in order to prevent the development of hypotension and placental hypoperfusion (net ultrafiltration for each session of hemodialysis should be $\leq 500 \mathrm{ml}$ ) (34). Every day hemodialysis ( $>20 \mathrm{~h} /$ week) improves the removal of uremic toxins, provides hemodynamic stability for the pregnant woman and optimal placental perfusion. Bicarbonate solution is used for hemodialysis (the concentration of bicarbonate $25 \mathrm{mmol} / \mathrm{l}$ ), with the concentration of sodium of 135 $\mathrm{mmol} / \mathrm{l}$. Unfractionated heparin is used for anticoagulation of extracorporeal circulation(that does not cross the placenta) (34). With haemodynamically unstable pregnant women in a critical condition, with acute renal failure and insufficiency of multiple organ systems, as a supportive dialysis therapy, continuous dialysis modalities are used (34).

\section{CONCLUSION}

Acute kidney damage associated with pregnancy is a factor in the risk of an adverse outcome for the mother and fetus. Early detection and timely appropriate treatment of acute kidney damage requires good equipment of obstetric units, precise monitoring of mothers and fetus, team approach, enhanced cooperation between obstetrician and nephrologist, all in order to correct the outcome for the mother and fetus during pathological pregnancy. 
Sheme 1. Pathogenesis of preeclampsia

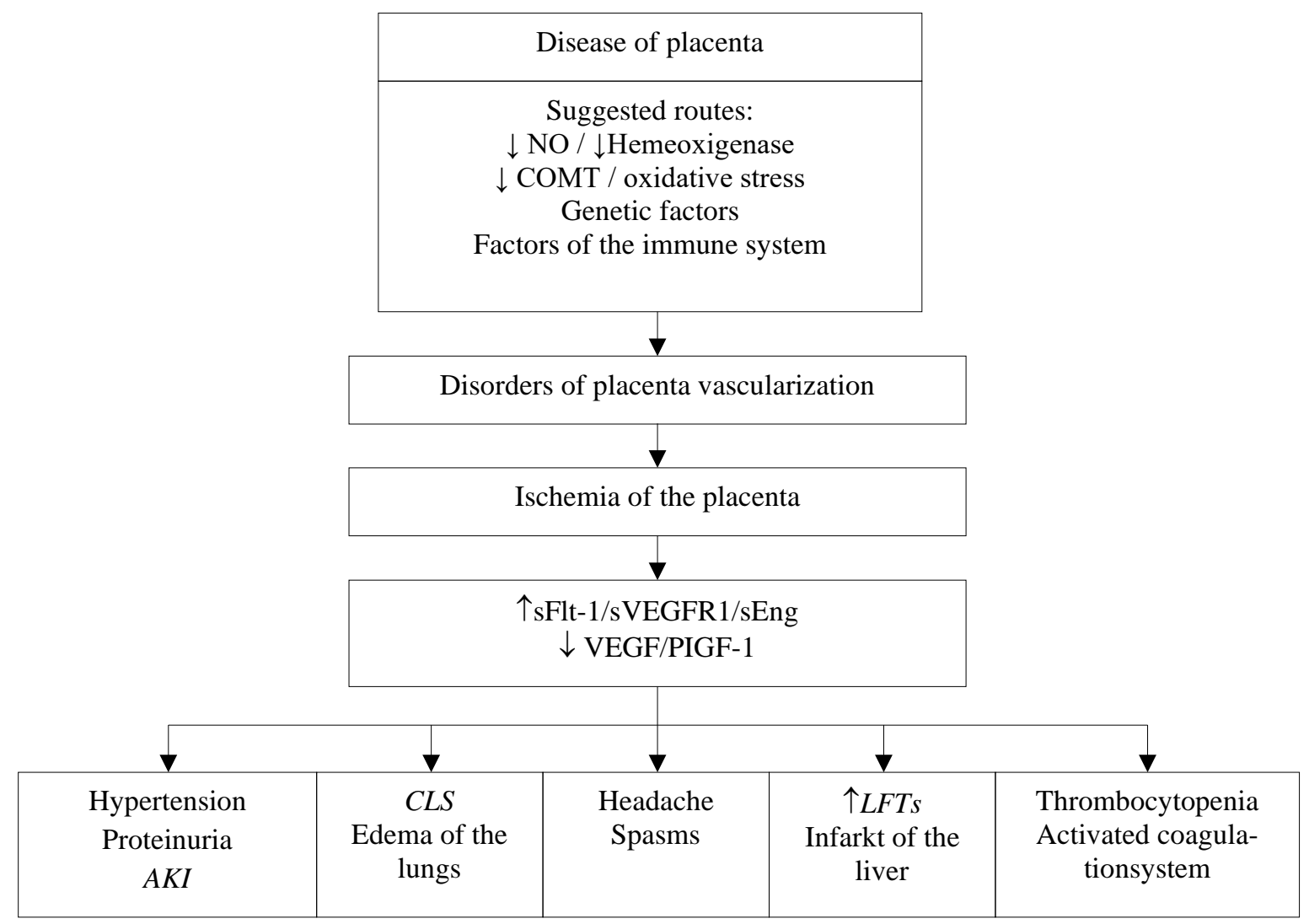

AKI - Acute Kidney Injury, CLS - Capillary Leak Syndrome, NO - Nitric Oxide, COMT - Catechol-O-methyltransferase, LFT - Liver Function Test, PIGF-1 - Placental Growth Factor-1, sEng - soluble Endoglin, sFlt-1 - soluble Fms-like tyrosine kinase-1, sVEGFR1 - soluble Vascular Endothelial Growth Factor Receptor-1 - VEGF - Vascular Endothelial Growth Factor Modified in accordance to reference [3].

\section{ACKNOWLEDGMENTS}

Authors would like to express their gratitude to the Ministry of Education, Science and Technological Development of the Republic of Serbia for the Grant N0175014, which was used as one of the sources to financially support this scientific paper.

\section{REFERENCES}

1. Asharya A, Santos J, Linde B, Anis K. Acute Kidney Injury in Pregnancy-Current Status. Adv Chronic Kidney Dis 2013; 20(3): 215-22.

2. Jim B, Garovic VD. Acute Kidney Injury. SeminNephrol 2017; 37(4): 378-85.

3. Jim B, Karumanchi SA. Preeclampsia: Pathogenesis, Prevention, and Long-Term Complications. SeminNephrol 2017; 37(4): 386-97.

4. Chaiworapongsa $\mathrm{T}$, Chaemsaithong P, Yeo L, Romero R. Pre-eclampsia part 1: current understanding of its pathophysiology. Nat Rev Nephrol 2014; 10(8): 466-80.

5. Naljayan MV, Karumanchi SA. New Developments in the Pathogenesis of Preeclampsia. Adv Chronic Kidney Dis 2013; 20(3): 265-70.

6. Chaiworapongsa T, Chaemsaithong P, Korzeniewski SJ, Yeo L, Romero R. Pre-eclampsia part 2: prediction, prevention and management. Nat Rev Nephrol 2014; 10(9): 531-40. 
7. Petrović D. Preeklampsija i eklampsija: etiopatogeneza, dijagnostika i lečenje. U: Trudnoća i bubreg u kliničkojpraksi. Ed. Petrović D. Kragujevac, Interprint, Fakultetmedicinskihnauka 2016: 47-65.

8. Haram K, Svendsen E, Abildgaard U. The HELLP syndrome: Clinical issues and management. A Review. BMC Pregnancy and Childbirth 2009; 9(1): 8-23. [doi: 10.1186/1471-2393-9-8].

9. Simetka O, Klat J, Gumulec J, Dolezalkova E, Salounova D, Kacerovsky M. Early identification of women with HELLP syndrome who need plasma exchange after delivery. Transfus Apher Sci 2015; 52(1): 54-9.

10. Erkurt MA, Berktas HB, Kuku I, Kaya E, Koroglu M, Nizam I, et al. A life-saving therapy in Class I HELLP syndrome: Therapeutic plasma exchange. Transfus Apher Sci 2015; 52(2): 194-8.

11. Petrović D, Tirmenštajn-Janković B, Živanović M, Petrović-Nikolić A, Nikolić A, Đurđević P, et al. Plazmafereza: osnovni principi i klinički značaj u trudnoći. Timoč Med Glas 2016; 41(1): 41-54.

12. Schwartz J, Padmanabhan A, Aqui N, Balogun RA, Connelly-Smith L, Delaney $\mathrm{M}$, et al. Guidelines on the Use of Therapeutic Apheresis in Clinical Practice - Evidence-Based Approach from the Writing Committee of the American Society for Apheresis: The Seventh Special Issue. J ClinApher 2016; 31(3): 149-338.

13. Tran TT, Ahn J, Reau N. ACG Clinical Guideline: Liver Disease and Pregnancy. Am J Gastroenterol 2016; 11(2): 176-94.

14. Westbrook RH, Dusheiko G, Williamson C. Pregnancy and liver disease. J Hepatol 2016; 64(4): 933-45.

15. Licata A, Calvaruso V, Primignani M, Morisco F, Bugianesi E, Invernizzi P, et al. AISF position paper on liver disease and pregnancy. Dig Liver Dis 2015; 48(2): 120-37.

16. Fakhouri F, Vercel C, Fremeaux-Bacchi V. Obstretic Nephrology: AKI and Thrombotic Microangiopathies in Pregnancy. Clin J Am SocNephrol 2012; 7(12): 2100-6.

17. Kavanagh D, Goodship TH, Richards A. Atypical Hemolityc Uremic Syndrome. Semin Nephrol 2013; 33(6): 508-30.

18. NorisM, Remuzzi G. Overview of Complement Activation and Regulation. Semin Nephrol 2013; 33(6): 47992.

19. Petrović D, Čanović P, Mijailović Ž, Popovska-Jovičić B, Jaćović S. Hemolitičko-uremijski sindrom: etiopatogeneza, dijagnostika i osnovni principi lečenja. Med Čas 2015; 49(2): 59-65.

20. Schwartz J, Padmanabhan A, Aqui N, Balogun RA, Connelly-Smith L, Delaney M, et al. Guidelines on the Use of Therapeutic Apheresis in Clinical Practice - Evidence-Based Approach from the Writing Committee of the American Society for Apheresis: The Seventh Special Issue. J ClinApher 2016; 31(3): 149-338.
21. Clark WF, Huang SHS, Walsh MW, Farah M, Hildebrand AM, Sontrop JM. Plasmapheresis for the treatment of kidney diseases. Kidney Int 2016; 90(5): 97484.

22. Andries G, Karass M, Yandrapilli S, Linder K, Liu D, Nelson J, et al. Atypical hemolytic uremic syndrome in first trimester pregnancy successfully treated with eculizumab. ExpHematolOncol 2017; 6: 4. Doi: 10.1186/s40164-017-0064-7.

23. De Sousa-Amorim E, Pelicano MB, Quintana LF, Campistol JM. Eculizumab in pregnancy-associated atypical hemolytic uremic syndrome: insights for optimizing management. J Nephrol 2015; 28(5): 641-5.

24. Zuber J, Fakhouri F, Roumenina LT, Loirat C, Fremeaux-Bacchi $\mathrm{V}$ on behalf of the French Study Group for aHUS/C3G. Use of eculizumab for atypical haemolyticuraemic syndrome and C3 glomerulopathies. Nat Rev Nephrol 2012; 8(11): 643-57.

25. Keating GM. Eculizumab: A Review of Its Use in Atypical HaemolyticUraemic Syndrome. Drugs 2013; 73(18): 2053-66.

26. Gately R, San A, Kurtkoti J, Parnham A. Life-threatening pregnancy-associated atypical haemoliticuraemic syndrome and its response to eculizumab. Nephrology 2017; 22(Suppl 1): 32-5.

27. Trestioreanu AZ, Fraser A, Gafter-Gvili A, Paul M, Leibovici L. Antibiotics for preventing meningoccal infections. Cochrane Database Syst Rev 2013; 10: CD004785. Doi:10.1002/14651858.CD004785.pub5.

28. Scully M, Thomas M, Underwood M, Watson H, Langley K, Camilleri RS. Thrombotic thrombocytopenic purpura and pregnancy: presentation, management, and subsequent pregnancy outcomes. Blood 2014; 124(2): 211-9.

29. Todorović Ž, Jovanović M, Todorović D, Petrović D, Đurđević P. Thrombotic thrombocytopenic purpura: etiopathogenesis, diagnostics and basic principles of treatment. Ser J ExpClin Res 2017; 18(1): 61-8.

30. Sayani FA, Abrams CS. How I treat refractory thrombotic thrombocytopenic purpura. Blood 2015; 125(25): 3860-7.

31. Chakravarty EF, Murray ER, Kelman A, Farmer P. Pregnancy outcomes after maternal exposure to rituximab. Blood 2011; 117(5): 1499-506.

32. Petrović D. Akutno oštećenje bubrega: etiologija, dijagnostika i lečenje.Medicinska Istraživanja 2011;45(3):713.

33. Acharya A. Management of Acute Kidney Injury in Pregnancy for the Obstetrician. ObstetGynecolClin N Am 2016; 43(4): 747-65.

34. Machado S, Figueiredo N, Borges A, Sao Jose Pais M, Freitas L, Moura P. Acute kidney injury in pregnancy: a clinical challenge. J Nephrol 2012; 25(1): 19-30. 